Eskişehir Osmangazi Üniversitesi

Sosyal Bilimler Dergisi

Haziran 2020, 21(1), 163-185

DOI: 10.17494/ogusbd.763587

\title{
Avrupa Parlamentosu Seçimlerinde 40 Yıl: 1979 - 2019
}

\author{
Gökhan AKŞEMSETTiNOĞLU*
}

Avrupa Parlamentosu Seçimlerinde 40 Yıl: 1979-2019

Özet

Bu çalışma, 1979-2019 yılları arasında doğrudan genel oy ilkesi kapsamında yapılan Avrupa Parlamentosu seçimleri hakkında bilgi vermekte ve 2019 seçimleri sonucu oluşan Avrupa Parlamentosu'ndaki siyasi parti gruplarını tanıtmaktadır. Çalışmada nitel veri analizi ve tümevarım yöntembilimi kullanılmıştır. Bu çalışmanın amacı, Avrupa Birliği (AB) vatandaşlarının genel siyasi eğilimleri hakkında bilgi sahibi olmak ve toplumu etkileyen olaylara karşı $A B$ vatandaşlarının değişen bakış açılarını, $A B$ toplumunun sesi olan Avrupa Parlamentosu içindeki siyasi oluşumları analiz ederek anlamaya çalışmaktır. Bu makale, Avrupa Parlamentosu seçimlerinin kırk yıllık tarihini karşılaştırmalı olarak bir çalışma altında topladığı ve mevcut Avrupa Parlamentosu'nu oluşturan siyasi parti gruplarını tanıttığı için önemlidir. $B u$ çalışmada, genel olarak $A B$ vatandaşlarının ılımlı bir siyasi atmosferi tercih ettiği anlaşılmıştır. Ayrıca, $A B$ içinde yaşanan krizlerin ve $A B$ dışında ortaya çıkan uluslararası gelişmelerin, Avrupa Parlamentosu'nu oluşturan siyasi grupları etkilediği de ortaya çıkmaktadır.

Anahtar Kelimeler: Avrupa Parlamentosu, Doğrudan Genel Seçimler, 2019 Seçimleri, Siyasi Parti Grupları

Makale Türü: Araştırma
40 Years in the European Parliament Elections: 1979 2019

Abstract

This study provides information about the European Parliament elections held under direct universal suffrage in 1979-2019 and introduces political party groups in the European Parliament generated as a result of the 2019 elections. In this study, qualitative data analysis and induction methodology are used. The aim of this study is to learn about the general political tendencies of European Union (EU) citizens and to try to understand the changing perspectives of the EU citizens against the events that affect the society by analysing the political formations within the European Parliament, which is the voice of the EU society. This article is important because it gathers the forty-year history of the European Parliament under comparative study and introduces the political party groups that make up the current European Parliament. In this study, mainly it is understood that the EU citizens prefer a moderate political atmosphere. In addition, the crises within the EU and international developments outside the EU affect the political groups that make up the European Parliament.

Keywords: European Parliament, Direct Universal Suffrage, 2019 Elections, Political Party Groups

Paper Type: Research

\section{Giriş}

Avrupa Birliği $(A B)$ 'nin yedi temel kurumundan biri olan ve $A B$ yasama sürecinin Konsey ile birlikte ana karar-alma organı olan Avrupa Parlamentosu (AP), ilk olarak "Ortak Meclis" adı altında, 18 Nisan 1951 tarihinde imzalanan Paris Antlaşması'yla oluşturulan Avrupa Kömür ve Çelik Topluluğu'nun (AKÇT) bir kurumu olarak ortaya çıkmıştır. Dolayısıyla, Paris Antlaşması'nın 20. maddesine göre üye devletlerin halklarının temsilcilerinden oluşturulacak olan Ortak Meclis, denetleme yetkisine sahip olacak, aynı antlaşmanın 22. maddesine göre de AKÇT'nin diğer kurumları olan Konsey'in ve Yüksek Otoriteyi oluşturan üyelerin çoğunluğunun isteği üzerine olağanüstü

*Gökhan AKŞEMSETTiNOĞLU, Doç. Dr. Çankaya Üniversitesi, Siyaset Bilimi ve Uluslararası illişkiler Bölümü, gokhana@cankaya.edu.tr, ORCID ID orcid.org / 0000-0002-6990-6834 
toplanarak görüş bildirecektir (Rudden ve Wyatt, 1986: 8). 25 Mart 1957 tarihinde akdedilen Roma Antlaşması ile oluşturulan Avrupa Ekonomik Topluluğu (AET) ile Avrupa Atom Enerjisi Topluluğu (AAET)'nun da kurumlarından biri olan Ortak Meclis'e Roma Antlaşması́nın 137. maddesine göre denetim yetkisi dışında danışma görevi de verilmiştir (Rudden ve Wyatt, 1986: 75). Aslında, Roma Antlaşması'nın 138 (3) maddesinde Meclis seçimlerinin “Doğrudan Genel Oy" ilkesine göre yapılacağı belirtilmiş olmasına rağmen (Rudden ve Wyatt, 1986: 76), ilk Meclis, altı üye devletin ulusal parlamentolarından atanan ve yarı-zamanlı çalışan 78 parlamenterden oluşmuştur. Ortak Meclis, 1962 yılında adını Avrupa Parlamentosu olarak değiştirmiştir. 8 Nisan 1965 tarihinde imzalanan ve her üç topluluğun (AKÇT, AET, AAET) yasama ve idari organlarını birleştiren Füzyon (Birleşme) Antlaşması'yla AP, her üç topluluğun ortak bir kurumu haline gelmiştir.

Topluluğun kurulduğu ilk yıllarda sadece denetim ve danışma görevlerini üstlenen AP, 1970'li yıllarda yapılan ve kurucu antlaşmaların bazı hükümlerini değiştiren antlaşmalar ile gücünü artırmıştır. Örneğin, 22 Temmuz 1975 tarihinde imzalanan Brüksel Antlaşması (Antlaşmaların Bazı Mali Hükümlerini Değiştiren Antlaşma), bir "bütçe usulü" oluşturmuş ve AP'ye bütçeyi reddetme yetkisi tanımıştır. 22 Nisan 1970 tarihinde yapılan Konsey toplantısında da AP seçimlerinin doğrudan genel oy ilkesine göre yapılması konusunda anlaşııış, 19-21 Ekim 1972 tarihinde toplanan Paris Zirvesi'nde Roma Antlaşması'nın 138. maddesi hatırlatılarak, AP seçimlerinin doğrudan genel oy ilkesine göre yapılması konusu, devlet ve hükümet başkanları tarafından kabul edilmiştir. Böylece 20 Eylül 1976 tarihinde imzalanan “Meclis Temsilcilerinin Doğrudan Genel Oy Yöntemiyle Seçilmesine Ilişkin Kanun" ile AP seçimlerinin doğrudan genel oy ilkesine göre yapılması konusu hukuki bir nitelik kazanmıştır. Bu kanun 1 Temmuz 1978 tarihinde yürürlüğe girmiş ve doğrudan genel oy ilkesine göre ilk seçimler 7-10 Haziran 1979 tarihinde yapılmıştır.

Böylece Avrupa Topluluğu (AT)/AB üyesi ülkelerin vatandaşları, 1979 yılından itibaren her beş yılda bir doğrudan genel oy ilkesi çerçevesinde yapılan seçimler yoluyla AP'nin temsilcilerini belirlemektedir. Dünyadaki ilk ve tek uluslararası parlamento seçimleri olan AP seçimlerine üye devletlerdeki benzer ideolojiye sahip ulusal partilerin oluşturduğu siyasi parti grupları katılmaktadır. Bir başka deyişle, AP'de temsilciler vatandaşlık esasına göre değil, siyasi ideolojileri temsil eden siyasi gruplar vasıtasıyla belirlenmektedir. Aynı zamanda, AB'nin tarih içindeki gelişimi ile Avrupa Parlamentosu'ndaki siyasi parti gruplarının gelişimi ve değişimi arasında bir paralellik olduğunu da belirtmek gerekir (Kiriş, 2013: 125). Son AP seçimleri, 23-26 Mayıs 2019 tarihleri arasında 28 üye devlet arasında yapılmış ve Avrupa Parlamentosu'nda 2024 yılına kadar görev yapacak parlamenterler seçilmiştir.

Avrupa toplumunun sesi olan ve $A B$ vatandaşlarının eğilimlerini yansıtan Avrupa Parlamentosu'na odaklanan bu çalışmanın bir biriyle alakalı iki amacı vardır: AP'nin 1979-2014 yılları arasında yapılan seçimlerini de kısaca hatırlatarak, 2019 seçimleri hakkında bilgi vermek ve 2019 seçimleri sonunda Parlamento'ya giren siyasi parti gruplarını tanıtmak. "Nitel Veri Analizi" üzerine oturan ve "Tümevarım” yöntembilimini kullanan bu çalışmaya ait bilgiler çoğunlukla $A B^{\prime}$ nin resmi kaynaklarına dayanmaktadır. Bu çalışma için anket, görüşme gibi yöntemler kullanılmadı̆̆ı (ve çalışmanın verileri 2020 yılından önce toplandığı) için etik kurul iznine gerek bulunmamaktadır. Bu 
çalışma, AP'nin 1979-2019 döneminde yapılan seçimlere topluca vurgu yaptığı, dolayısıyla Avrupa toplumunun siyasi görüşlerini yansıttığı ve 2019 seçimleri sonucu Avrupa Parlamentosu'na giren siyasi parti gruplarının oluşmasına sebep olan ulusal dinamikleri, beş büyük üye devletin siyasi gelişmelerine vurgu yaparak açıklamaya çalıştığı için önemlidir. Bir başka deyişle, bu çalışma, $A B$ toplumunun 40 yıllık siyasi duruşu hakkında bilgi vermektedir.

Bu çalışma, giriş ve sonuç bölümleri hariç tutulmak üzere, beş bölümden oluşmaktadır. Birinci bölümde, AP'nin yapısı ve işlevleri hakkında bilgi verilerek, AP'nin özellikle 1980 'li yılların ortasından itibaren kazandığı güç ve Avrupa bütünleşme süreci içindeki önemi açıklanmıştır. İkinci bölüm, 2019 seçimlerine göre AP'deki siyasi parti gruplarını tanıtmaktadır. Bu bölümde yedi siyasal parti grubu hakkında açıklayıcı bilgiler verilmektedir. Üçüncü ve dördüncü bölümler AP seçimleri hakkındadır. Üçüncü bölüm, AP'nin 1979-2014 yılları arasında yaptığı sekiz seçimi kapsarken, dördünce bölüm, AP'nin 2019 seçimlerini açıklamaktadır. Bu bölüm sonunda AB vatandaşlarıly ilgili Eurobarometre (Eurobarometer) tarafından sağlanan kısa istatistiki bilgiler de verilmektedir. Dolayısıyla, üçüncü ve dördüncü bölümler AP'nin 40 yı içinde yaptığı dokuz seçimle oluşturduğu siyasi yapısını tarihi gelişmeler içinde incelemektedir. Çalışmanın beşinci bölümünde, elde edilen bulgular açıklanmakta, araştırmanın genel bir değerlendirmesi yapılmaktadır.

\section{Avrupa Parlamentosu'nun Yapısı ve İşlevleri}

Önce, 17 Şubat 1986 tarihinde Lüksemburg'da, sonra 28 Şubat 1986 tarihinde Lahey'de imzalanan Avrupa Tek Senedi (ATS) kurucu antlaşmalarda köklü değişiklikler yapmıştır. ATS, tek pazarı 1992'ye kadar tamamlayacak süreci hızlandırmak için, "işbirliği usulü" ve "onay usulü" gibi kararları benimseyerek AP'nin gücünü artırmıştır. Tek Senet, işbirliği usulü ile AP'nin "iki okuma” yapmasına izin vererek, $A P^{\prime}$ nin önerilen yasa tasarılarını geciktirme, değiştirme ve engelleme gücüne kavuşmasını sağlamıştır. Tek Senet, onay usulü ile de AP'ye yasa tasarısı dışındaki kararlar için onay verme yetkisi getirmiştir. Buna göre, örneğin, genişleme süreci içinde Birliğin aday ülkeleri kabulü öncesi AP'nin onayını zorunlu kılmıştır.

1990'lı yıllardaki gelişmeler, AP'ye özellikle kanun yapma sürecinde büyük yetkiler vermiştir. 7 Şubat 1992 tarihinde imzalanarak, 1 Kasım 1993 tarihinde yürürlüğe giren Avrupa Birliği Antlaşması (Maastricht Antlaşması) bu konuda köşe taşı niteliğinde bir özelliğe sahiptir. Maastricht Antlaşması, AP'ye Konsey ile birlikte "ortak karar alma" yetkisi vermiştir. Böylece, AB'de AP ile Konsey arasında doğrudan görüşmeler yoluyla ortak karar alma süreci başlamıştır. Benzer şekilde, Maastricht Antlaşması, onay usulünün içeriğini genişleterek, $A P^{\prime} y e$, görevine başlamadan önce Komisyonu bir bütün olarak onaylama yetkisi vermiştir. 1990'lı yılların sonu ile 2000'li yılların başındaki diğer düzenlemeler, AP'ye verilen yetkilerin içeriklerini genişletir mahiyettedir. Örneğin, 2 Ekim 1997 tarihinde imzalanan Amsterdam ve 26 Şubat 2001 tarihinde imzalanan Nice Antlaşmaları ile ortak karar alma ve onay usullerinin uygulama alanları genişletilmiş, söz konusu usullere konu olan politika alanlarının sayısı artırılmıştır.

Avrupa bütünleşme sürecinde bir diğer dönüm noktası, 13 Aralık 2007 tarihinde imzalanarak, 1 Aralık 2009 tarihinde işlerlik kazanan Lizbon Antlaşması'dır. Lizbon Antlaşması, yeniden düzenlenen 
"Avrupa Birliği Antlaşması" (ABA) ile yeniden düzenlenen Roma Antlaşması ve aynı zamanda yeniden isimlendirilen “Avrupa Birliği'nin İşleyişi Antlaşması” (ABIA) üzerine oturmakta ve gerçek bir Birlik kurmaktadır. Böylece AB tüzel bir kişilik kazanmıştır. Lizbon Antlaşması, AP'nin 50 yı içinde kazandığı gücü pekiştirmiş ve etki alanını genişletmiştir. $A B A^{\prime}$ nın 14. maddesi, $A P^{\prime}$ nin görevlerini tanımlamaktadır. Buna göre, Birlik vatandaşlarının temsilcilerinden oluşan AP, Konsey ile birlikte karar alır, bütçe ile ilgili karar verir, diğer kurumlara danışmanlık yapar ve Komisyon başkanını seçer (Günuğur, 2014: 341).

ABIA'nın 223-234 maddeleri, AP'nin işleyişi hakkındadır. Bu maddelere göre; örneğin, Konsey, AP üyelerinin çoğunluğunun olumlu oyu ile karar almaktadır. Benzer biçimde, AP, Konsey'in nitelikli çoğunluğunun olumlu oyu ve tüzükler çıkararak ilgili düzenlemeleri yapmaktadır (Günuğur, 2014: 487-491). Lizbon Antlaşması, ortak karar alma yöntemini, “Olağan Yasama Yöntemi” olarak kabul etmiş ve bu yöntem ile alınan kararların alanını genişletmiş̧ir. Lizbon Antlaşması ile AP'nin üye sayısı da sabitlenmiştir. Genişleme süreçleri ve Birliğe yeni katılan ülkelerle birlikte üye sayısı sürekli değişen AP'de sandalye sayısı AP başkanı ile birlikte 751 olarak sabitlenmiştir. Parlamento'da vatandaşların temsili giderek azalan oransal temsile göre yapılmakta ve delegeler 96-6 (üst ve alt sınırlar) arasında üye devletlerarasında dağıtılmaktadır. AP'de çoğunluğu sağlamak için 376 sandalye gerekmektedir. $A B$ üyesi ülkelerin vatandaşları oylarını ya vatandaşı oldukları üye ülkelerde ya da ikamet ettikleri bir $A B$ üyesi ülkede kullanabilmektedir. AP seçimleri, üye ülkelerin ulusal düzenlemelerine göre yapılmaktadır. Bu yüzden oy kullanma yaşı, oy barajı gibi konular, üye ülkelerin kendi anayasalarına göre düzenlenmektedir. Örneğin, genel olarak seçimlere katılım yaşı 18 iken, Avusturya ve Malta'da bu rakam 16 olarak düzenlenmiştir. Ayrıca, Belçika, Lüksemburg, Yunanistan, Bulgaristan ve Güney Kıbrıs Rum Yönetimi (GKRY), seçimlere katılımı zorunlu kılmaktadır.

AP’nin ilk görevi, Komisyon önerileri için danışma niteliğinde görüş bildirmek olmasına rağmen, zaman içinde farklı işlevlere sahip bir kurum olarak Avrupa bütünleşme süreci içinde önemli bir yere sahip olmuştur. AP’nin ilk önemli işlevi, yasama işlevidir. Önce işbirliği yöntemi ile alınan kararlar hakkında söz sahibi olmaya başlayan AP, ortak karar alma yöntemi ile karar alma mekanizmasını Konsey ile ayakta tutan son derece önemli bir kurum olmuştur. Dolayısıyla, günümüzde olağan yasama yöntemi olarak tanımlanan $A B$ karar alma yapısı, AP sayesinde demokratik bir nitelik kazanmıştır. AP'nin ikinci önemli işlevi, siyasi işlevidir. Buna göre, AB'nin yeni politikalar geliştirmesinde veya mevcut politikaları değiştirmesinde bir forum niteliği taşıyan AP'nin yeri oldukça önemlidir. Hem Komisyon'un hem de Konsey'in söz konusu politikalar hakkında AP'yi bilgilendirmesi ve $A P^{\prime}$ den görüş istemesi, $A P^{\prime}$ nin politika yapım süreci içindeki ağırlığını ortaya koymaktadır. Komisyon'un AP'ye her yı “AB'nin Faaliyetleri Hakkında Genel bir Rapor” vermesi ve Avrupa Konseyi'nin de yapılan görüşmeleri AP'ye bildirmesi, $A P^{\prime}$ nin $A B$ siyaseti içindeki yerini göstermektedir. AP'nin üçüncü işlevi, denetimle ilgili işlevidir. AP, genel olarak Komisyonu bir bütün olarak denetlemekte, Birlik müktesebatının uygulanması konusunda yaşanan sorunları araştırmakta, kötü yönetim ile ilgili geçici soruşturma komiteleri oluşturabilmektedir. AP, ciddi yönetim hataları veya yolsuzluk gibi durumlarda gensoru önergesi verebilmekte ve gerekirse 
üyelerinin üçte iki çoğunluğunun kararı ile Komisyonu bir bütün olarak istifaya zorlayabilmektedir. Örneğin, 1999 yılında (Jacques) Santer Komisyonu, görevi kötüye kullanma iddiaları araştırıırken, topluca görevi bırakmak zorunda kalmıştır. AP, kötü yönetimle ilgili iddiaları ve vatandaşların şikâyetlerini dinlemek üzere kendi bünyesi içinde bir "Kamu Denetçisi" (Ombudsman) de atamaktadır. AP'nin dördüncü işlevi, bütçe ile ilgilidir. AP, Birlik içindeki harcamaları kontrol etmekte, Komisyon'un bütçe önerisini kabul veya reddedebilmektedir. Örneğin, AP, 1979 ve 1984 yıllarına ait bütçeleri reddetmiştir. $A P^{\prime}$ nin bütçe üzerindeki yetkisi $A B^{\prime}$ nin demokratikleştirilmesi konusunda atılan önemli adımlardan biridir.

Uzmanlık alanlarına göre ayrılmış 20 Komiteye sahip olan AP'de siyasi grup oluşturabilmek için en az yedi üye ülkeyi temsil eden 25 milletvekili gerekmektedir. Ayrıca, ulusal parti adaylarının AP'ye milletvekili gönderebilmeleri için ülkelerindeki oyların yüzde beşini almaları zorunludur. AP'de bir başkan, bir başkan yardımcısı ve Komitelerin başkanları vardır. Sekretaryası Lüksemburg'da bulunan AP'nin Genel Kurul toplantıları her ay bir hafta süre ile Fransa'nın Strazburg kentinde toplanmaktadır. 1999'dan itibaren seçimler "orantılı temsil” esasına göre yapılmaktadır. 2019 seçimlerine göre AP'ye yedi siyasi parti grubu girmiştir.

\section{2019 Seçimlerine Göre Avrupa Parlamentosưndaki Siyasi Parti Grupları}

\subsection{Avrupa Halk Partisi (EPP)}

Avrupa Halk Partisi, milliyetçi akımlara karşı dini ön plana çıkararak Avrupa'daki halkları bir araya getirmeyi amaçlayan bir siyasi hareket olarak ortaya çıkmıştır. Hristiyan Demokratlar (Hristiyan dini geleneği ve ahlakına dayanan merkez sağ bir ideoloji) olarak da bilinen Avrupa Halk Partisi, Avrupa'daki en büyük siyasal parti grubu olarak 1976 yılında kurulmuştur. Kendisini Avrupa bütünleşme projesinin sahibi olarak gören bu parti; Hristiyan demokrasi, sosyal piyasa modeli, Iımlı muhafazakârlık (tarihi ve kültürel mirasa bağlı, öz değerlerin değişmesine karşı gelişen bir siyasi görüş), aile değerleri, özgürlük, adalet ve dayanışma ilkelerini benimsemektedir. Bu siyasi parti grubu, toplumda devletin ve kilisenin, politikanın ve dinin rollerinin belirlenmesinin, $A B$ içindeki çeşitliliğe katkı sağlayacağını ve ortak sorunlara ortak çözümler getireceğini savunmaktadır. En eski siyasal parti grubu olan bu merkez-sağ partinin hedefi daha rekabetçi ve demokratik bir Avrupa oluşturmaktır (EPP Group in the European Parliament, 2019). Dolayısıyla, grubun amacl, demokrasiyi güçlendirerek, kurumlarının güvenirliğini sağlamak ve vatandaşlarının, insan onuru, özgürlük, insan hakları, hukuk devleti, dayanışma ve yerindelik (subsidiarite) ilkelerini benimsediği bir Birleşik Avrupa yaratmaktır (EPP Group, Our Missions and Values, 2019).

\subsection{Sosyalistlerin ve Demokratların Ilerici İttifakı (S\&D)}

Bu siyasi parti grubu, Avrupa Sosyalist Partisi ile İtalya'daki sol eğilimli demokratların oluşturduğu İtalyan Demokrat Partisi'nin bir araya gelerek oluşturdukları bir gruptur. 1952 yılında Sosyalist Grubun ortaya çıkması, bu siyasi parti grubunun temeli olarak kabul edilebilir. 1957'de Sosyalist Partiler Bürosu'nun kurulması ile güçlenen sosyalistler, 1960'da hedeflerinin Avrupa Birleşik Devletleri'ni kurmak olduğunu açıklamışlardır. 1970'de "Sosyal Bir Avrupa'ya Doğru Programı'”nın açıklanması ve 1980'de Sosyalist Partilerin Konfederasyonu'nun oluşturulması, 1992 
yılında Avrupa Sosyalist Partisi'nin kurulması ile sonuçlanmış ve söz konusu siyasi parti grubunun en önemli ayağını oluşturmuştur. Bu siyasi parti grubu, "Avrupa Ortak Geleceğimiz Programı" çerçevesinde istihdam, çevre, demokrasi ve Birlik vatandaşlığı, hoşgörü, genişleme konularına vurgu yapmıştır. 1993'de asgari ücretin iyileştirilmesi ve asgari çalışma şartlarının sağlanması konusunda önemli bir çalışma başlatan bu grup; kadın-erkek eşitliği, tüketicinin korunması, sürdürülebilir ekonomi, iklim değişikliği, yenilenebilir enerji, sosyal politikalar ile ortak tarım ve balıkçılık konuları üzerinde çalışmaktadır.

\subsection{Avrupa'yı Yenile}

İlk defa adın 2019 seçimlerinde duyduğumuz bu siyasi oluşumun kökleri, 1947 yılında ortaya çıkan Liberal Enternasyonal'e kadar geri gitmektedir. 1953 yılında Liberal ve Demokratik Grubun kurulması ve 1979 yılında Avrupa Liberal Demokratlarının ortaya çıkması diğer önemli tarihi adımları oluşturmaktadır. 1986 yılında kurulan Avrupa Liberal Demokrat ve Reform Partileri (ELDR) 1993 yılında bir Avrupa partisi haline geldikten sonra 2005 yılında Avrupa Liberalleri ve Demokratları Itttifakı (ALDE) adını almıştır. 1990'lı yıllarda, liberal demokrasiyi, özgürlüğü, açık toplumu, sürdürülebilir kalkınmayı, hesap verebilirliği savunan bu siyasi oluşum, 2000'li yıllarda ilkelerini beş grup altında toplamıştır. Buna göre demokrasiyi korumak ve geliştirmek, finansal istikrarı oluşturmak, istihdam yaratmak ve çevreyi korumak grubun temel ilkeleri arasındadır. Bu siyasi parti grubunun anlayışına göre, Avrupa'da hiçbir devlet iklim değişikliğine, uluslararası terörizme ve küreselleşmenin olumsuz etkilerine tek başına cevap veremeyeceğinden, devletlerin bir araya gelmesi kaçınılmazdır (Renew Europe, 2019).

\subsection{Yeşiller ve Avrupa Özgür İttifakı (EFA)}

Yeşiller ve Avrupa Özgür İttifakı, çoğunlukla Avrupa'da yeşil hareketi savunan çevrecilerden ve üye devletlerdeki azınlıklardan oluşmaktadır. Yeşiller, 1981'de bir siyasi parti içinde faaliyetlerini sürdürmeye başlamış, 1984'den sonra da etkili bir siyasi güç olmuşlardır (The Greens/EFA, About the Group, 2019). Yeşiller, 1992'de Rio'da düzenlenen “Dünya Zirvesi” sırasında fikirlerini dünyaya yayma olanağı bulmuşlar ve Kyoto Protokolü’nün hazırlanmasına aktif katılım sağlamışlardır. Yeşiller ayrıca 1995 yılında, Fransa'nın Mururoa Atollerindeki nükleer tesislerini protesto ederek geniş bir anti-nükleer kampanya başlatmışlardır. Yeşiller, 1998'de Avrupa Komisyonu'ndaki görevi kötüye kullanma ve adam kayırma konusuna el atarak, 1999'da Santer Komisyonu'nun istifa etmesine sebep olmuşlardır (The Greens/EFA, About the Group, 2019). Bu grup, 1999-2004 döneminde, Yugoslavya'daki soykııım sebebiyle anti-militarizm konusuna vurgu yapmış, Balkanlardaki sorunların barışçı yollardan çözümü konusunda Verona Forum'u oluşturmuştur. Yeşiller, 2003 yılında organik tarımı öne çıkararak, bir yiyecek kampanyası da başlatmışlardır. 2004 seçimlerinde kurulan Avrupa Yeşil Partisi, 2009 yılında yayınladıkları "Avrupa için Yeni bir Yeşil Bakış" başlıkı bir manifesto ile Yeşillerin önceliklerinin belirlenmesini sağlamıştır. Buna göre; çevrenin korunması, barış, sosyal adalet, adil küreselleşme ve insan hakları Yeşillerin öncelikleri arasındadır. Benzer şeklide, iklim değişikliği, cinsiyet eşitliği, yiyecek güvenliği de Yeşillerin yeni ilgi alanları arasına girmiş, 2000 
sonrasında da küçük "Sivil Toplum Kuruluşları" (STK) işbirlikleri, tüketicinin korunması gibi konular bu ilgi alanlarına eklenmiştir (The Greens/EFA, About the Group, 2019).

\subsection{Kimlik ve Demokrasi (ID)}

$A B^{\prime}$ nin federalistlerin arzuladığı gibi tamamen ulus-üstü bir yapı haline gelmesini istemediği bir diğer siyasi parti grubu da Kimlik ve Demokrasi (ID) grubudur. 2019 seçimlerinden öncesi adları Avrupa Ulusları ve Özgürlük Grubu (ENF) olan bu grup için devletin egemenliği ve egemen devletlerarasındaki işbirliği önceliklidir. Devlete verdikleri önem, bu grup üyeleri için kimliği ön plana çıkarmaktadır. Grup üyeleri, kimliğin korunması için hareket etmekte, göç ve ilticanın kontrol edilmesinin ve kısıtlanmasının, kimliğin korunmasında önemli olduğunu belirtmektedir. Siyasi projelerini demokratik ilkelere uygunluk üzerine kuran bu siyasi parti grubu, halkları temsil eden devletlerin, halkların kültürel, sosyal ve ekonomik özelliklerini korumanın önemini vurgulamaktadır. Devletlerin sahip oldukları ve kendilerine kimliklerini kazandıran söz konusu kültürel ve sosyal değerlerin korunmasında halkın önemini vurgulamaktadırlar (Identity and Democracy Party, 2019).

\subsection{Avrupa Muhafazakârlar ve Reformistler Grubu (ECR)}

Avrupa Muhafazakârlar ve Reformistler Grubu, ulusal, muhafazakâr, ekonomik liberalizmi savunan ancak bütünleşmeye mesafeli, federalist olmayan merkez-sağ bir gruptur. 2009 yılında bu siyasi parti grubu, üye devletlerin egemenliğine saygı, ekonomik olarak yeniden yapılandırma, büyüme ve rekabetçilik konularında reform yapabilmek amacıyla Avrupa Muhafazakârlar ve Reformistler İttifakı ile Avrupa Hristiyan Siyasal Hareketi'nin bir araya gelmesiyle oluşturulmuştur (ECR Group, About, 2019). "Euro-gerçekçilik" bu grubu diğerlerinden ayıran bir özelliktir. Buna göre $A B$, yeni bir yöne ihtiyaç duymaktadır. Avrupa yanlısı ve Avrupa-karşıtı alternatif yaklaşımlar arasında bu grup, ortak çıkarların olduğu alanlarda işbirliği yapan bir uluslar toplumunu savunmaktadır. Grubun bir başka hedefi, $A B$ vatandaşlarıyla AB kurumları arasında mesafeyi kapatmak, vatandaşları Brüksel'e yaklaştırmaktır. Bunun için de üye devletlere eşit davranmak ve AB'yi mali anlamda daha sorumlu hale getirmek önemlidir. Bu siyasi parti grubu aynı zamanda göç akımı, terörizm gibi küresel tehditlere karşı, $A B^{\prime}$ nin küresel çözümler bulmaya çalışarak, Birliğin dünya üzerinde oynadığı rolü de artırabileceğini savunmaktadır (ECR Group, About, 2019). ECR, birçok girişime önayak olmuştur. Örneğin, "Yolcu İsim Kaydı" uygulaması hem yolcuların isimlerinin diğer üye ülkelerle paylaşılmasında hem de polis güçleriyle işbirliği yapılmasında oldukça etkili bir yöntemdir. Benzer şekilde “Avrupa Suçlu Kayıt Bilgi Sistemi” üye olmayan devlet vatandaşlarının suçla ilgili kayıtlarını tutan bir bilgi sistemidir. Bu sistemle, suçların önceden önlenmesi mümkün olmaktadır (ECR Group, Protecting and Respecting Member States, 2019).

\subsection{Avrupa Birleşik Solu / Nordik Yeşil Sol (GUE / NGL)}

Doğrudan seçimlerle birlikte, $A P^{\prime}$ deki sol-kanat parlamenterleri bir araya getiren bu siyasi parti grubu, 1989 yılında İtalya, İspanya, Danimarka ve Yunanistan'dan dört partinin "Başka bir Avrupa Mümkün" sloganıyla bir araya gelmesiyle kurulmuştur. Önce "Avrupa Uniteryen Solu” adını kullanan grup, 1992'den itibaren "Avrupa Birleşik Solu” adını kullanmaya başlamıştır. 1993 yılında İtalyan CP partisi, adını PDS olarak değiştirmiş ve Avrupa Birleşik Sol'unu (GUE) AP'deki Sosyalist gruba 
taşımıştır (GUE/NGL, History, 2019). AB’nin 1995 yılındaki genişlemesi sonrası, Danimarka'dan Sosyalist Halkçı Parti'nin gruba yeniden katılmasıyla birlikte Danimarka, İsveç ve Finlandiya partileri Kuzey Yeşil Solunu mevcut siyasi grubun bir parçası haline getirmişlerdir. Dolayısıyla bu siyasi grup, GUE/NGL olarak yeniden isimlendirilmiştir (GUE/NGL, History, 2019). Temel amaçları arasında; istihdam ve eğitim, sosyal güvenlik ve eşitlik, kültürel değişim, uluslararası dayanışma, sürdürülebilir ekonomik kalkınma, vatandaşların demokrasiye aktif katılımının sağlanması olan bu siyasi grup, Avrupa bütünleşme projesini bir "halk projesi" olarak görmektedir (GUE/NGL, About the Group, 2019). GUE/NGL, AB'nin mevcut ticaret politikasına alternatif olarak, şeffaflık ve demokrasi, çevre ve iklim değişikliği, işçi hakları, sosyal ve insan hakları, vergi, halkın bilgiye ulaşımı gibi kavramların üzerinde durmaktadır (GUE/NGL, New Report: Towards a Progressive Trade Politics in the EU, 2019).

\section{Avrupa Parlamentosu 1979-2014 Seçimleri}

\subsection{Seçimleri}

1970'li yıllar, uluslararası para sisteminin çökmesi, petrol krizleri ve yaşanan ekonomik sıkıntılar ile İngiltere'nin üye olduktan sonra ulus-üstü bütünleşme hareketlerini yavaşlatma çabası gibi, çoğunlukla olumsuz gelişmelere sahne olmuştur. Dolayısıyla bu dönem üye devletlerin Avrupa bütünleşme süreci için "kötümser" oldukları bir dönemdir. Öte yandan, ilk doğrudan genel seçimler de bu dönemde yapılmıştır. 1979 seçimlerinde merkez-sol ve merkez-sağ gruplar birbirine yakın oylar alarak, Parlamento'daki sandalyelerin yarısından fazlasına sahip olmuşlardır. Bu eğilim, Topluluk vatandaşlarının radikal siyasi gruplar yerine, merkezdeki siyasi gruplara prim verdiklerini göstermiş, böylece aslında Avrupa Parlamentosu'nun 40 yıllık seçim tarihindeki temel dinamiğini de ilk doğrudan genel seçimlerde ortaya koymuştur. Bu seçimlerde dokuz üye devletin vatandaşları \% 63 oranında bir katılım gerçekleştirmişlerdir. Bu, aynı zamanda şimdiye kadarki ilk ve tek en yüksek katıım oranı olmuştur. Bu seçimlerde üye devletler farklı seçim yöntemleri kullanmışlardır. Örneğin İngiltere "çoklu oy" sistemini kullanırken, diğer üye devletler "orantılı temsil" yöntemini tercih etmiştir. Bu seçimlerde en az katılım İngiltere'de gerçekleşirken (\% 32,2), sandığa en çok rağbet edenler italyan'lar olmuştur (\% 84,9) (About Parliament, 2019).

Tablo 1. 1979 Yılı Avrupa Parlamentosu Seçimleri

Gruplar Oy Oranı

S (Sosyalist Parti)

PPE (Avrupa Halk Partisi Grubu)

ED (Avrupa Demokratik Grubu)

15.37 
COM (Komünist ve Müttefik Grubu)

10.73

L (Liberal ve Demokratik Grup)

DEP (Avrupa İlerici Demokratlar Grubu)

CDI (Bağımsız Grupların ve Üyelerin Teknik Koordinasyon ve Savunma Grubu)

2.68

NI (Bağımsızlar)

2.44

Kaynak: Avrupa Parlamentosu

\subsection{Seçimleri}

1980'li yılların ikinci yarısı, Avrupa bütünleşme sürecinin hız kazandığı dönemdir. Özellikle, 1985 yılında iş başına gelen (Jacques) Delors Komisyonu, Topluluğun hız kazanmasında önemli rol oynamıştır. 1980'li yılların ilk yarısında Amerika Birleşik Devletleri (ABD) ve Japonya'nın dünya piyasalarında hâkim rol oynamaya başlaması, Topluluğun bütünleşme projesine hız vermesi, örneğin Tek Pazarı tamamlaması için itici güç olmuştur. Uluslararası piyasaların rekabetine sahne olan bu dönemde yapılan 1984 seçimleri, merkezdeki iki siyasi grubu yeniden ilk iki sıraya yerleştirirken, küçük gruplar arasında ilk ittifak girişimleri ortaya çıkmıştır. Merkezdeki Sosyal Demokratlar bir önceki seçime göre oy oranlarını yüzde ikinin üzerinde artııırken, özellikle Fransız Ulusal Cephe ile İtalyan Sosyal Hareketinin ittifakı ile kurulan aşırı sağ grup (DR), bütünleşme projesine ve ulus-üstü yapılanmaya karşı ortaya çıkan ilk ittifak olmuştur. Benzer biçimde Yeşiller de diğer sol gruplarla bir araya gelerek Gökkuşağı grubunu oluşturmuşlardır (ARC). Katılımın \% 61 olarak gerçekleştiği, 1984 seçimlerinde merkez-sol ve merkez-sağ partilerle aşırı-sol ve aşırı-sağ partiler arasında önemli ayrım olduğu görülmüştür. Topluluk vatandaşları, ılımlı siyasi hedefleri olan partileri ödüllendirirken, radikal söyleme sahip partilere ve siyasi gruplara, prim vermeyeceklerini ortaya koymuşlardır (About Parliament, 2019).

Tablo 2. 1984 Yılı Avrupa Parlamentosu Seçimleri

\begin{tabular}{ll}
\hline \hline Gruplar & Oy Oranı \\
\hline S (Sosyalist Parti) & 29.95 \\
PPE (Avrupa Halk Partisi Grubu) & 25.35 \\
ED (Avrupa Demokratik Grubu) & 11.52 \\
COM (Komünist ve Müttefik Grubu) & 9.45 \\
L (Liberal ve Demokratik Grup) & 7.14 \\
RDE (Avrupa Demokratik Ittifak Grubu) & 6.68 \\
\hline
\end{tabular}


ARC (Avrupa Parlamentosu'nda Gökkuşağı Grubu)

4.61

DR (Avrupa Hakları Grubu)

$\mathrm{NI}$ (Bağımsızlar)

Kaynak: Avrupa Parlamentosu

\subsection{Seçimleri}

Yukarıda da belirtildiği gibi 1985 yılında Komisyon başkanı olan Jacques Delors, bütünleşme projesinin hızlanmasında önemli rol oynamıştır. Avrupa Tek Senedinin kabul edilmesini ve kurucu antlaşmaların düzeltilmesini içeren bu süreç aynı zamanda Tek Pazar'ın tamamlanması konusunda Delors'un sorumluluk aldığı, örneğin "tarife dışı engellerin" ortadan kaldırılması konusunda ciddi önlemler aldığı bir dönem olmuştur. Bu siyasi atmosferde yapılan 1989 seçimlerinde Sosyal Demokratlar Parlamento'daki etkilerini artırmışlardır. Sosyal Demokratların bir önceki seçime göre oy oranlarını neredeyse yüzde dört artırmalarında, Sosyalist Delors'un büyük payı olmuştur. Bir önceki seçimlerle karşılaştırıldı̆̆ında Demokratlar önemli oy kaybına uğramışlar, Liberaller de bu seçimlerde sandalye sayılarını artırarak ilk defa AP'de üçüncü sırada yer almışlardır (LDR). Katııımın \% 59 olarak gerçekleştiği 1989 seçimlerinde küçük siyasi gruplar (RDE, DR, CG, ARC gibi) yaptıkları ittifaklara rağmen başarılı olamamışlardır. Dolayısıyla bu seçimlerde de, Topluluk üyesi vatandaşların radikal oluşumlara geçit vermeyeceği anlaşılmıştır (About Parliament, 2019).

Tablo 3. 1989 Yılı Avrupa Parlamentosu Seçimleri

\begin{tabular}{ll}
\hline \hline Gruplar & Oy Oranı \\
\hline S (Sosyalist Parti) & 34.75 \\
PPE (Avrupa Halk Partisi Grubu) & 23.36 \\
LDR (Liberal ve Demokratik Reformist Grup) & 9.46 \\
ED (Avrupa Demokratik Grubu) & 6.56 \\
V (Avrupa Parlamentosu'ndaki Yeşil Grup) & 5.79 \\
GUE (Avrupa Birleşik Solu Konfedere Grubu) & 5.41 \\
RDE (Avrupa Demokratik ittifak Grubu) & 3.86 \\
DR (Avrupa Hakları Grubu) & 3.28 \\
CG (Sol Birlik) & 2.70 \\
ARC (Avrupa Parlamentosu'nda Gökkuşağı Grubu) & 2.51 \\
NI (Bağımsızlar) & 2.00 \\
\hline
\end{tabular}


Kaynak: Avrupa Parlamentosu

\subsection{Seçimleri}

Soğuk Savaş'ın bitişi ve uluslararası arenada hâkim olan belirsizlik, etkisini Birlik üzerinde de göstermiştir. Üye devletler, 1992 yılının Aralık ayında imzaladıkları Maastricht Antlaşması ile Soğuk Savaş'ın belirsizliklerine karşı yeni düzenlemeler yapmış ve Topluluğu bir Birliğe dönüştürmüşlerdir. Bütünleşme ve ayrışmanın aynı anda yaşandığı, yeni devletlerin ortaya çıktığı bu çok önemli dönemde yapılan 1994 seçimlerinde, Sosyal Demokratlarla Hristiyan Demokratlar merkez siyasi gruplar olarak Parlamento'da dengeyi korumalarına rağmen, Hristiyan Demokratların, bir önceki seçime göre oylarını yüzde dört oranında artırdıkları gözlemlenmiştir. Dolayısıyla, Soğuk Savaş'ın belirsizlikleri, üye devletlerin Hristiyan köklerini hatırlamalarına yardımcı olmuştur. Bu seçimlerde ilk defa Hristiyan Demokratlarla diğer Muhafazakârlar ittifak yapmışlardır. Bir başka deyişle, Soğuk Savaşın bitişiyle birlikte ortaya çıkan gelişmeler, Sovyetler Birliği'nin dağılması ve Komünizmin sona ermesi, iki Almanya'nın birleşmesi ve Yugoslavya'nın parçalanması, sağ partileri oluşturan grupların AP içindeki etkilerini artırmıştır. Yine, bu etkilerin bir parçası olarak, ilk Avrupa-şüphecisi partinin (EDN) Parlamento'ya girerek bir ilki gerçekleştirdiğini ve yüzde üçün üzerinde oy aldığını da belirtmek gerekir. Katılımın \% 57 olarak gerçekleştiği 1994 seçimlerinde, yine radikal, sosyal liberal partilerin bir araya gelerek yeni bir grup oluşturdukları (ARE) da vurgulanmalıdır (About Parliament, 2019).

Tablo 4. 1994 Yılı Avrupa Parlamentosu Seçimleri

\begin{tabular}{ll}
\hline \hline Gruplar & Oy Oranı \\
\hline PSE (Avrupa Sosyalistleri Partisi Grubu) & 34.92 \\
PPE (Avrupa Halk Partisi Grubu) & 27.51 \\
ELDR (Avrupa Liberal, Demokrat ve Reform Partisi Grubu) & 7.76 \\
GUE (Avrupa Birleşik Solu Konfedere Grubu) & 4.94 \\
FE (ileri Avrupa Grubu) & 4.76 \\
RDE (Avrupa Demokratik İttifak Grubu) & 4.59 \\
V (Avrupa Parlamentosu'ndaki Yeşil Grup) & 4.06 \\
ARE (Avrupa Radikal İttifak Grubu) & 3.35 \\
EDN (Avrupa Uluslar Grubu - Koordinasyon Grubu) & 3.35 \\
NI (Bağımsılar) & 4.76 \\
\hline
\end{tabular}

Kaynak: Avrupa Parlamentosu 


\subsection{Seçimleri}

Illk dört Parlamento seçimlerinden birinci parti olarak çıkan Sosyal Demokratlar, 1999 seçimlerinde ikinci parti durumuna düşmüşler ve bu durum günümüze kadar devam etmiştir. Merkez partiler arasındaki yer değişikliğinin sebebi, Soğuk Savaş'ın olumsuz etkilerinin yüzyılın sonunda da devam etmesidir. Dolayısıyla, Sovyetler Birliği'nden ayrılan Merkezi ve Doğu Avrupa Ülkeleri'nin (MDAÜ) geleceklerini sorgulaması, üye devletleri, bir kez daha bütünleşme projesinin önemli katalizörlerinden biri olan Hristiyanlık ortak kimliği altında buluşturmuştur. Bu dönemde, kendilerini tehdit altında hisseden Birlik vatandaşlarının merkezde, ancak muhafazakâr tepkiler verdiğini görüyoruz. Bu seçimlerde Hristiyan Demokratların diğer demokratlarla bir ittifak kurduklarını da hatırlatmak gerekir (EPP-ED). 1999 seçimlerinde, Hristiyan Demokratlar ve Sosyal Demokratlar, yer değiştirseler de, ilk iki sırayı paylaşarak geleneksel Parlamento yapısını korumuşlardır. Bu seçim, merkezdeki grupların yüksek oy aldıkları bir seçim olmuştur. Bu seçimlerde katılım ilk defa \% 50'nin altına düşerek \% 49,8 olmuştur. Bu durum 2019 seçimlerine kadar devam edecektir (About Parliament, 2019).

Tablo 5. 1999 Yılı Avrupa Parlamentosu Seçimleri

\begin{tabular}{ll}
\hline \hline Gruplar & Oy Oranı \\
\hline EPP-ED (Avrupa Halk Partisi ve Avrupa Demokratları Grubu) & 37.06 \\
PSE (Avrupa Sosyalistleri Partisi Grubu) & 28.75 \\
ELDR (Avrupa Liberal, Demokrat ve Reform Partisi Grubu) & 7.99 \\
Verts/ALE (Yeşiller Grubu / Avrupa Serbest İttifakı) & 7.67 \\
GUE/NGL (Avrupa Birleşik Solu / Nordik Yeşil Sol) & 6.71 \\
UEN (Ulusların Avrupası için Birlik Grubu) & 4.95 \\
TDI (Bağımsız Üyeler Teknik Grubu - Karma Grup) & 2.88 \\
EDD (Demokrasiler ve Çeşitliliklerin Avrupası Grubu) & 2.56 \\
NI (Bağımsızlar) & 1.00 \\
\hline
\end{tabular}

Kaynak: Avrupa Parlamentosu

\subsection{Seçimleri}

2004 Mayıs'ında AB, en büyük genişlemesi ile 25 üyeye ulaşmış ve MDAÜ'lerinin katııımıyla yeni sorunlarla yüzleşmeye başlamıştır. Böylece, yeni katılan üyelerin hepsi aynı gelişmişlik düzeyinde olmadığı için bu ülkelerin Birliğe uyum sağlamaları için bir hazmetme süreci de başlamıştır. Bu dönemde üye olması beklenen Bulgaristan ve Romanya ise ciddi yapısal ve idari sorunlarını çözmeleri için 2007'ye kadar bekleyeceklerdir. Katılımın \% 45'e düştüŭü 2004 seçimlerinde dikkat çeken, $A B$-şüphecilerinin sayısının artması ve GUE/NGL, IND/DEM ve Verts/ALE gibi siyasi grupların 
Parlamento içinde ittifak yaparak güçlenmeye başlamalarıdır. Bu seçimler ilk defa merkezdeki iki ana siyasi grubun oy kaybetmeye başladıkları ilk seçimlerdir. Bu siyasi gruplar günümüze kadar ilk iki sıradaki yerlerini korumalarına rağmen, sandalye kaybetmeye devam edeceklerdir. Bir başka deyişle, $A B^{\prime}$ de karar-alma mekanizması içinde söz sahibi olan partiler önemli oy kaybına uğrarken,

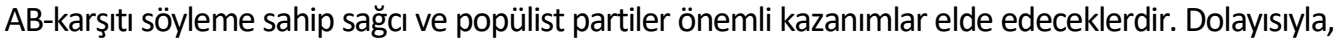
yeni üyelerin getireceği sorunlar partiler tarafından tartışlırken, sağ partiler güç kazanmaya başlamışlardır (About Parliament, 2019). Bu dönemde sağ partilerin güç kazanmaya başlamalarının en önemli sebebi, 11 Eylül saldırılarının AB vatandaşları üzerinde yarattığı tesirdir. 11 Eylül 2001 tarihinde New York'ta bulunan Dünya Ticaret Merkezi'ne El Kaide tarafından yapılan saldırılar, dünyada özellikle Müslümanlara karşı uzun süredir devam eden önyargllara yenilerini eklemiştir. El Kaidenin Madrid (2004) ve Londra (2005) saldırıları, Avrupa kamuoyundaki korkuları güçlendirmiş, radikal sağ partilerin cazibesini artırmıştır. 11 Eylül saldırılarıyla yeni bir boyut kazanan siyasal gündem, aşırı milliyetçiliği öne çıkaran, çok-kültürlülük anlayışına ve kozmopolit yaşam şekline karşı çıkan, ulus-üstü girişimleri desteklemeyen ve insanları "ötekileştirerek" etnik-merkezli politikaları savunan radikal/aşırı sağ partilerin $A B$ içinde beklenenin ötesinde destek görmesine sebep olmuştur.

Tablo 6. 2004 Yılı Avrupa Parlamentosu Seçimleri

\begin{tabular}{ll}
\hline \hline Gruplar & Oy Oranı \\
\hline EPP-ED (Avrupa Halk Partisi ve Avrupa Demokratları Grubu) & 36.61 \\
PSE (Avrupa Sosyalistleri Partisi Grubu) & 27.32 \\
ALDE (Avrupa için Liberaller ve Demokratlar İttifak Grubu) & 12.02 \\
Verts/ALE (Yeşiller Grubu / Avrupa Serbest İttifakı) & 5.74 \\
GUE/NGL (Avrupa Birleşik Solu / Nordik Yeşil Sol) & 5.60 \\
IND/DEM (Bağımsızlık / Demokrasi Grubu) & 5.05 \\
UEN (Ulusların Avrupası için Birlik Grubu) & 3.69 \\
NI (Bağımsızlar) & 3.96 \\
\hline
\end{tabular}

Kaynak: Avrupa Parlamentosu

\subsection{Seçimleri}

2009 Seçimlerinde Bulgaristan ve Romanya'nın da üye olmalarıyla 27 üyeye ulaşan $A B, \%$ 43'e düşen katılım oranıyla, vatandaşların bütünleşme projesine ilgilerini kaybetmeye başladıklarını göstermiştir. Bu dönemde vatandaşların seçimlere ilgi göstermemesinin sebeplerinden belki de en önemlisi, Anayasa Antlaşması'nın yürürlüğe girmemesinin yarattığı etkilerdir. Anayasa Antlaşması, Avrupa Birliği'nin geleceğini çerçevelemek ve Avrupa Birliği'ni uluslararası bir aktör haline getirmek amacıyla bir Konvansiyon tarafından hazırlanmış ve 29 Ekim 2004 tarihinde Roma'da imzalanarak kabul edilmiştir. Ancak antlaşma, onay süreci tamamlanamadığı için yürürlüğe girmemiştir. 
Antlaşma, 2005 yılında Fransa'da yapılan referandumda \% 55 oy oranı ve 2006 yılında Hollanda'da yapılan referandumda $\% 61,6$ oy oranı ile reddedilmiştir. Anayasa Antlaşması'nın reddedilmesi, $A B$ içinde büyük bir hayal kırıklığı yaratmıştır. Anayasa Antlaşması'nın reddedilmesi ile ilgili olarak birçok sebep öne sürülse de antlaşma metninin eski metinler üzerine kurulduğu, dolayısıyla planlanan hedeflere ulaşabilmek için gerekli olan yeni düzenlemeleri içermiyor olması ve federalist/ulusalcı (ulus-üstü/hükümetler arası) dengenin tam olarak sağlanamamış olması temel sebepler olarak kabul edilmektedir. Bununla birlikte, Avrupa Birliği'nde halkın genel olarak gelecekleri konusunda belirsizlikler yaşıyor olmaları ve hükümetlerinin icraatlarından memnun olmamaları da önemli sebepler arasındadır. Özellikle anayasanın oluşturulma sürecinde halka düşüncelerinin fazla sorulmaması, halkta bu girişimin bir “elit”" projesi olduğu izlenimini uyandırmıştır. Yine, Avro alanında ekonomik ve parasal birliğin tam olarak sağlanamamış olması ve ekonomik açıdan Anglosakson eğilimlerin gittikçe güçlenmesi de diğer sebepler arasında gösterilebilir. Genel olarak bu seçimlerde dikkat çeken, 1999 seçimlerinden itibaren Sosyal Demokratların istikrarlı bir şekilde oy kaybetmeleridir. 2009 seçimlerinde ittifaklardan vazgeçen Sosyal Demokratlar ve Hristiyan Demokratlar, eski kimliklerine geri dönmüşlerdir. Diğer yandan, radikal grupların oy oranlarını artırmaya başlamaları, AB'de işlerin iyi gitmediğinin göstergesi olmuştur. 2008 krizinin etkileri bir sonraki seçimde daha çok hissedilecektir (About Parliament, 2019).

Tablo 7. 2009 Yılı Avrupa Parlamentosu Seçimleri

\begin{tabular}{ll}
\hline \hline Gruplar & Oy Oranı \\
\hline EPP (Avrupa Halk Partisi) & 36.01 \\
S\&D (Sosyalistlerin ve Demokratların Illerici İttifakı) & 25.00 \\
ALDE (Avrupa için Liberaller ve Demokratlar İttifak Grubu) & 11.41 \\
Greens/EFA (Yeşiller Grubu / Avrupa Serbest İttifakı) & 7.47 \\
ECR (Avrupa Muhafazakârlar ve Reformistler Grubu) & 7.34 \\
GUE/NGL (Avrupa Birleşik Solu / Nordik Yeşil Sol) & 4.76 \\
EFD (Avrupa Özgürlük ve Demokrasi Grubu) & 4.35 \\
NI (Bağımsızlar) & 3.67 \\
\hline
\end{tabular}

Kaynak: Avrupa Parlamentosu

\subsection{Seçimleri}

2008 krizinin etkileriyle memnuniyetsizliği artan AB vatandaşları, 2014 seçimlerinde merkezdeki siyasi grupları ciddi şekilde cezalandırmıştır. Sosyal Demokratlar istikrarlı bir şekilde oy kaybetmeye devam ederken, en büyük düşüşü Hristiyan Demokratlar yaşamıştır. Bu seçimlerde Hristiyan Demokratların oyları, radikal, aşırı sağ partilere kaymıştır. ECR, Avrupa muhafazakârları olarak ilk defa üçüncü parti olarak seçimlerden çıkmıştır. Özellikle Danimarka, Fransa ve İngiltere'nin 
sağcı partilerinin yüksek oy aldığı seçimlerde AB-karşıtı söylemler önem kazanmıştır. Avrupa vatandaşları arasında 11 Eylül saldırılarıyla artan güvensizlik duygusu ve Müslümanlara karşı geliştirilen fobi, 2008 yılında $A B^{\prime}$ yi etkilemeye başlayan ekonomik/finansal kriz tarafından iyice körüklenmiştir. 2007 yılında likidite fazlalığı ve buna bağlı olarak üzerinde çok düşünülmeden verilen konut kredileriyle $A B D$ 'de başlayan ekonomik kriz daha sonra büyüyerek ABD'nin sınırlarını aşmış ve küresel bir krize dönüşmüştür. Avrupa Birliği de bu kriz ile 2008 yılında tanışmıştır. Ekonomik kriz yüzünden $A B^{\prime}$ nin uygulamaya koyduğu kemer sıkma politikaları, sosyal harcamaların kesintiye uğramasına ve işsizliğin artmasına sebep olmuş, bu da $A B$ vatandaşları arasında mevcut siyasi partilere ve yöneticilerine karşı memnuniyetsizliğe dönüşmüştür. Vatandaşların bu memnuniyetsizliği, aynı zamanda "yerel" ile "göçmen" arasındaki rekabetin sertleşmesine de sebep olmuş ve $A B$ vatandaşlarının güvenlik, kimlik ve refah ile ilgili kaygılarını artırmıştır.

Avrupa Birliği'nde aşırı sağ görüşün ve bu görüşü temsil eden siyasi partilerin önem kazanmasında rol oynayan "göçmen" konusunu tetikleyen bir başka önemli gelişme de "Arap Baharı" sonrasında yaşanmıştır. Baskıcı ve otoriter rejimlere karşı önce 2010 yılında Tunus'ta başlayan ve 2011 yılından sonra Mısır, Libya, Suriye, Bahreyn, Ürdün ve Yemen'e sıçrayan gösteri ve protestolar, komşu ülkeleri göç konusu ile karşı karşıya bırakmıştır. Bu siyasi hareket öncesi, “AB'nin bölgede uyguladığı projelerin istenilen verimi ve sonucu vermekte başarısız olması” (Noi, 2012: 15), $A B$ vatandaşları arasında hem $A B$ kurumları ve yöneticilerine karşı bir güvensizlik oluşturmuş hem de mülteci akımları konusunda ciddi bir endişe yaratmıştır. $A B$ vatandaşları bu konudaki tepki ve endişelerini aşırı sağ partilere yönelerek göstermiş ve bu eğilimlerini 2014 yılında yapılan AP seçimlerine yansıtmışlardır. Bu seçimler, $A B$ vatandaşlarının $A B^{\prime}$ nin değerlerinden uzaklaşmaya başladığını, bu projenin özellikle mali konularda başarısız olduğunu düşündüklerini göstermiştir. $B u$ seçimlerde, yeni bir uygulama olarak, seçimlerde en fazla oyu alan siyasi grubun, AB Komisyonu Başkanının belirlenmesinde en fazla etkiye sahip olması ilkesi (Spitzenkandidat) benimsenmiştir. Dolayısıyla, seçimlerden birinci parti olarak çıkan siyasi grubun gösterdiği aday, AB Komisyonu Başkanı olacaktır. 2014 Seçimlerinde katılım, 40 yılın en düşük oranı olan \% 42 olarak gerçekleşmiştir (About Parliament, 2019).

Tablo 8. 2014 Yılı Avrupa Parlamentosu Seçimleri

\begin{tabular}{ll}
\hline \hline Gruplar & Oy Oranı \\
\hline EPP (Avrupa Halk Partisi) & 29.43 \\
S\&D (Sosyalistlerin ve Demokratların İlerici İttifakı) & 25.43 \\
ECR (Avrupa Muhafazakârlar ve Reformistler Grubu) & 9.32 \\
ALDE (Avrupa için Liberaller ve Demokratlar İttifak Grubu) & 8.92 \\
GUE/NGL (Avrupa Birleşik Solu / Nordik Yeşil Sol) & 6.92 \\
Greens/EFA (Yeşiller ve Avrupa Özgür İttifakı) & 6.66
\end{tabular}


Kaynak: Avrupa Parlamentosu

\section{Avrupa Parlamentosu 2019 Seçimleri}

Avrupa Birliği'nin seçilerek atanan tek kurumu olan AP, 2019-2024 döneminde görev yapacak parlamenterlerini, 23-26 Mayıs 2019 tarihleri arasında 28 üye ülkede yapılan seçimlerle belirlemiştir. 2019 yılında kayıtlı 374 milyon seçmenin \% 50.62'si oy kullanmıştır. Hindistan'dan sonra en fazla seçmenin oy kullandığı demokratik seçim olan AP seçimlerine 177 ulusal siyasi partiyi temsilen yedi siyasi parti grubu katılmıştır. 2019 seçimlerinde Hristiyan Demokratlar 46, Sosyal Demokratlar 41 sandalye kaybetmelerine rağmen, en fazla oyu olan iki büyük siyasi grup olmayı başarmışlardır. 2019 seçimlerinin sonuçları, Avrupa'da değişen siyasi durumun doğrudan bir sonucudur (Kaymakçı, 2019: 24). Dolayısıyla bu seçimlerden Avrupa'da çevre ve iklim değişikliği konularını gündeme getiren Yeşiller ve Liberaller güçlenerek çıkmışlardır. Yeşiller, sandalye sayılarını 74'e çıkararak dördüncü büyük siyasi grup olmayı başarmışlardır. Böylece Yeşiller, kararların alınmasında etkili olacaklardır (European Election Results, 2019).

2019 yılında yapılan son seçimlerde dikkat çeken konulardan biri, gençlerin seçimlere katılımındaki artıştır. 2014 seçimlerinde gençlerin katıımı \% 28 civarındayken, 2019 seçimlerinde bu oran \% 42 olarak gerçekleşmiştir. Gençler seçimlere en çok vatandaşlık görevlerini yerine getirmek ve oy ile değişimi sağlayabilmek için katıldıklarını belirtmişlerdir. İklim değişikliği ve çevre gibi konular, gençleri sandığa götüren diğer önemli sebepler arasında görünmektedir. Genel olarak bu seçimlerde $A B$ vatandaşlarının sandığa gitme sebepleri arasında ekonomik durum, iklim değişikliği ile insan hakları ve demokrasi ilk üç sırada gelmektedir (News, European Parliament, 2019). Dolayısıyla, 2019 seçimleri, iklim politikaları, göç ve mülteci sorunları başta olmak üzere, Avrupa kimliğini tanımlayan konuların tartışılacağını ortaya koymuştur.

$A B^{\prime}$ nin beş büyük üye devleti olan Almanya, Fransa, İtalya, İspanya ve İngiltere'deki siyasi partilerin durumu, 2019 seçimlerine önemli etkiler yapmıştır. Örneğin Almanya'nın merkezdeki ulusal partileri ciddi oranda kan kaybetmiş, Angela Merkel'in liderliğindeki merkez-sağ koalisyon partisi altı kayıpla 29 vekile düşerken, merkez-sol partisi de 11 kayıpla 16 sandalyeye gerilemiştir. Bu kayıplar, Parlamento seçimlerine de sırayla \% 28 ve \% 15 olarak yansımıştır. Almanya'da seçimlerde $\% 20$ oy alarak ikinci parti durumuna gelen Yeşiller, Parlamento'da da 21 sandalye kazanmışlardır. Almanya'da seçimlere katılım \% 61 oranında gerçekleşmiştir (European Election Results, Germany, 2019).

Son yıllarda terör saldırılarından etkilenen Fransa'da yabancı düşmanlığı artış göstermiş, bu da seçimlere aşırı sağ partilerin zaferi olarak yansımışır. 2019 seçimlerinde Fransa'da Marine Le Pen liderliğindeki aşırı sağ Milli Cephe Partisi \% 23 oy alarak en kazançlı çıkan parti olmuştur. Emmanuel Macron'un başında olduğu Cumhuriyetçi Yürüyüş Hareketi, \% 22 oy alarak ikinci parti durumuna düşmüştür. Bu sonuçlarla, Parlamento'da Milli Cephe Partisi 22 sandalye kazanırken, Cumhuriyetçi 
Yürüyüş Hareketi 21 sandalye almıştır. Almanya'da olduğu gibi Fransa'da da Yeşiller oy oranlarını artırarak \% 13 oranında oy almış, bu da Parlamento'ya 12 sandalye olarak yansımıştır. Fransa'da seçimlere katıım \% 50 oranında gerçekleşerek AB ortalamasını yakalamıştır (European Election Results, France, 2019).

Göç hareketlerinden en çok etkilenen üye devletlerden biri olan İtalya'da vatandaşların tepkilerini aşırı sağ partilere yönelerek verdiklerini görüyoruz. Özellikle göçmen karşıtı söylemlerle dikkati çeken aşırı sağ Lig Partisi \% 34 oy oranı ile birinci parti olurken, yine aşırı sağ Beş Yıldız Partisi \% 17 oy oranıyla üçüncü sırada yer almıştır. İtalya'da, merkezdeki Demokrat Parti \% 22 oy oranıyla ikinci parti olmuştur. Dolayısıyla, İtalya'da merkez sağ ve merkez sol partiler beklenen başarıyı gösterememiştir. İtalya'da seçimlere katılım \% 54 olarak gerçekleşmiştir (European Election Results, Italy, 2019).

AB üyeleri arasında seçimlerde Parlamento'nun alışıldık yapısına en yakın sonuçlar İspanya seçimlerinde çıkmıştır. İspanya'da Sosyal Demokratlar \% 32 oy oranıyla Parlamento'da 20 sandalye sahibi olurken, diğer merkez partisi, Popüler Parti, \% 20 oy oranıyla Parlamento'da 12 sandalye sahibi olmuştur. Diğer büyük devletlerin aksine, aşırı sağcı VOX partisi yüzde altı oy oranında kalmış ve Parlamento'da ancak üç sandalye sahibi olabilmiştir. İspanya'da seçimlere katılım \% 60 oranında gerçekleşmiştir (European Election Results, Spain, 2019).

İngiltere'de Bağımsızlık Partisi'nin eski lideri Nigel Farage, İngiltere'nin Birlikten ayrılamamasını eleştirerek Brexit Partisi'ni kurmuş, bu parti İngiltere'de Liberal Demokrat Parti'nin önünde \% 30 oranında oy alarak birinci parti olmuştur. Bu durum, seçimlere $\% 36$ oranında katılım gerçekleştiren Ingiliz halkının, seçimlere değil, $A B^{\prime}$ den ayrılma konusuna odaklandığını ancak anlaşmalı ayrılığın henüz gerçekleşmemesinin sorumlusu olarak gördüğü muhafazakâr partiyi cezalandırdığı anlamına gelmektedir. Bir başka deyişle, İngiltere'nin AB'den ayrılma konusunda süregelen belirsizliğin İngiliz vatandaşları arasında büyük bir hayal kırıklığı yarattığı görülmektedir. Bu seçimlerin İngiltere ile ilgili ilginç olan bir başka yanı da Birlikten ayrılma süreci içinde olan Ingiltere'nin AB'den kopuş tarihi olan 29 Mart 2019'un 31 Ekim 2019'a ertelemesiyle seçimlere girmek durumunda kalmış olmasıdır. Buna göre, seçimlerde İngiltere'nin aldığı 73 sandalye, İngiltere AB'den ayrıldıktan sonra 14 üye devlet arasında dağıtılacaktır. İktidardaki Muhafazakâr Parti 1832'den beri ilk defa en az oy aldığı seçimi yaşamıştır (\% 59.29). İş̧i partisi de \% 18,3'e gerilemiş̧ir (European Election Results, UnitedKingdom, 2019).

Tablo 9. 2019 Yılı Avrupa Parlamentosu Seçimleri

\begin{tabular}{ll}
\hline \hline Gruplar & OyOranı \\
\hline EPP (Avrupa Halk Partisi) & 24.23 \\
S\&D (Sosyalistlerin ve Demokratların Ilerici Ittifakı) & 20.51 \\
Renew Europe (Avrupa'yı Yenile) & 14.38 \\
Greens/EFA (Yeşiller ve Avrupa Özgür İttifakı) & 9.85
\end{tabular}


ID (Kimlik ve Demokrasi) $\quad 9.72$

ECR (Avrupa Muhafazakârlar ve Reformistler Grubu) $\quad 8.26$

GUE/NGL (Avrupa Birleşik Solu / Nordik Yeşil Sol) $\quad 5.46$

NI (Bağımsızlar) $\quad 7.59$

Kaynak: Avrupa Parlamentosu

Avrupa Parlamentosu'ndaki siyasi parti grupları ve 1979-2019 yılları arasında yapılan seçimlerle ilgili verilen bilgilerin sonunda belki $A B$ vatandaşlarının bu siyasi parti seçimleri ve genel olarak siyasi eğilimleri ile ilgili kısa bir istatistiki bilgi vermek faydalı olabilir. Buna göre, Eurobarometre verileri, Avrupa Birliği'nde vatandaşların çoğunun siyasete "ortalama" düzeyde (\% 48) ilgi duyduklarını, siyasete "çok fazla" ve çok az" ilgi duyanların oranının \% 17 olduğunu ortaya koymaktadır. Bu çerçevede $A B$ vatandaşları en çok ulusal, sonra yerel, sonra da Avrupa düzeyindeki politikalara ilgi duymaktadırlar (Standard Eurobarometer 90, 2018: 37). Benzer şekilde seçmenler ideolojik olarak kendilerini \% 33 oranında "ortada", \% 29 oranında "solda" ve \% 19 oranında da "sağda" tanımlamaktadırlar. AB vatandaşları, parti seçimiyle ilgili olarak; \% 20 oranında seçtikleri partilerin Avrupa düzeyinde yapacaklarını beyan ettikleri fikirler ile kendi fikirlerinin örtüşmesini göstermişlerdir. Vatandaşların sadece yüzde ikisi seçim süresince yapılan tartışmalardan ve görüşmelerden etkilenerek seçtikleri partilere oy vermişlerdir (Eurobarometer Survey 91,5, 2019). 2019 yılında yapılan anketlere göre, AB vatandaşlarının \% 51'i bölgesel veya yerel otoritelere güvendiklerini açıklarken, bu rakam ulusal hükümetler için \% 32 ve siyasi partiler için \% 19 olarak gerçekleşmiştir (Special Eurobarometer 486, 2019: 100). $A B$ vatandaşlarının \% 43’ü, $A B$ ve $A B^{\prime}$ nin vatandaşları üzerindeki günlük etkileri hakkında daha fazla bilgi alabilseler, seçimlere katılım oranının yükseleceğini düşünmektedirler. Benzer şekilde vatandaşların \% 31'i, gençlerin ve \% 20'si de kadınların daha fazla milletvekili adayı olmaları durumunda halkın seçimlere katıımının artacağını düşündüklerini bildirmişlerdir. $A B$ vatandaşlarının seçimlerle ilgili olarak olumsuz görüş bildirdikleri konular arasında ilk sırayı \% 61 ile seçimlerin siber saldıılar yoluyla manipüle edilmesi almaktadır. Bunu \% 59 ile dış güçlerin ve suç gruplarının seçimleri etkilediği görüşü izlemektedir. Yine halkın yaklaşık \% 55'i seçim sonuçlarının manipüle edildiğini düşünmektedirler (Special Eurobarometer 477, 2018: 6-12).

Avrupa Parlamentosu'nun 1979-2019 yılları arasında doğrudan seçimlerle oluşturduğu ve yukarıda kısaca açıklanmaya çalışılan özellikleri ortaya bazı bulgular çıkarmaktadır.

\section{Bulgular}

Avrupa Parlamentosu'nun 40 yıllık seçim tarihi bazı özellikleri ortaya koymaktadır. İlk özellik, Avrupa Birliği vatandaşlarının ıımlı siyasi söylemleri tercih ettiği ve bu söylemleri dile getiren siyasi grupları desteklemeleridir. Dolayısıyla, seçim tarihinin başından itibaren, 1999 seçimlerine kadar birinci sırada yer alan merkezdeki Sosyal Demokratlar ile 1999 seçimlerinden sonra birinci sıraya yerleşen merkezdeki Hristiyan Demokratlar ilk iki sırayı paylaşmışlardır. Radikal (aşıı sağ) siyasi 
partilerin AP'ye girmesi, çoğunluğu sağlayacak düzeye ulaşamamalarından, Parlamento'nun temel dinamiklerini bozmamıştır. Dolayısıyla, vatandaşların ıımlı siyasete verdikleri destek konusunda tutarlı bir davranış sergiledikleri söylenebilir.

İkinci özellik, Avrupa bütünleşme sürecinde yaşanan sorunların ve krizlerin, Birlik vatandaşlarını muhafazakâr eğilimler içine soktuğudur. Örneğin, 1970'li yıllarda üye devletleri etkileyen krizlerin (ve Avrupa-kötümserliğinin) 1980'li yılların ilk yarısında da devam etmesi, 1984 seçimlerinde ilk ittifak girişimlerinin ortaya çıkmasına ve bunun da sağ yönelimli partiler arasında olmasına sebep olmuştur. Benzer şekilde, özellikle demokrasileri ve ekonomileri sorgulanan Merkezi ve Doğu Avrupa Ülkeleri'nin üye olmalarıyla artan Avrupa-şüphecilerinin sayısı kendilerini 1999 ve 2009 seçimlerinde göstermiştir. Bu seçimlerde merkezdeki siyasi gruplar oy kaybetmeye başlarken muhafazakâr ve aşırı sağ gruplar oylarını artırmışlardır.

Üçüncü özellik, Birlik kurumlarının ve yöneticilerinin başarısının siyasi seçimlere yansıdığıdır. Örneğin, 1985 yılının başında Komisyon başkanı olan Sosyal Demokrat Jacques Delors'un, ortak pazarı tamamlamak için attığı adımlar ve tarife dışı engellerin kaldırılması konusunda aldığı kararlar, Birlik vatandaşları tarafından ödüllendirilmiş ve 1989 seçimlerinde Sosyal Demokratların oylarının artmasına sebep olmuştur. Dolayısıyla, siyasi kişiliklerin siyasi partilerin oy oranlarını artırması, ulusal düzeyde yapılan seçimlerde olduğu gibi Avrupa Parlamentosu seçimlerinde de etkili olmuştur.

Dördüncü özellik, uluslararası politikadaki değişikliklerin AP içindeki dinamikleri etkilemesidir. Örneğin Soğuk Savaş'ın bitişiyle birlikte ortaya çıkan belirsizlikler, AP içindeki muhafazakâr eğilimleri yeniden tetiklemiş, bu değişikliğin ilk etkileri 1994 seçimlerinde görülmüş, Hristiyan Demokratlar oylarını bir önceki seçime göre artırmışlardır. Dolayısıyla, genel bir eğlim olarak, Birlik, kriz durumlarında ve büyük değişimlerde Hıristiyanlığı sığınılacak, kuvvet alınacak bir yol olarak görmüştür. Her şeye rağmen AP'nin ilk seçimlerde ortaya koyduğu merkezi-lımlı siyaset eğiliminin, zaman zaman inişli-çıkışlı bir seyir izlese de son seçimlerde de devam ettiğini ve dolayısıyla $A B$ vatandaşlarının genel düşünce yapısını yansıttığını söyleyebiliriz.

Beşinci özellik, son seçimlere kadar AB vatandaşlarının AP seçimlerine fazla ilgi göstermemeleri ve seçimlere katılım oranının düşük seyretmesidir. Bir parlamentonun temel işlevleri, yasa çıkarmak, yürütmeyi gözetlemek ve denetlemek, dolayısıyla siyasal sistemin meşruiyetini korumaktır (Heywood, 2016: 235). Avrupa Parlamentosu'nun işlevlerine baktığımız zaman klasik parlamento tanımından uzaklaştığını görüyoruz. Örneğin Avrupa Parlamentosu'nun yasama teklifi verme yetkisinin olmaması ve kanun yapma yetkisini başka kurumlarla paylaşması, Avrupa Parlamentosu'nu diğer parlamentolardan ayırmakta ve meşruiyetini sorgular duruma getirmektedir. Gerçekten de Avrupa Birliği'nde yasama teklifi verme yetkisi Avrupa Komisyonu'ndadır. Yine, Avrupa Parlamentosu, kanun yapma yetkisini - olağan yasama yöntemi yoluyla - Avrupa Birliği Konseyi (Bakanlar Konseyi) ile paylaşmaktadır. Dolayısıyla, Avrupa Komisyonu ve Avrupa Birliği Konseyi gibi seçilmeyen kurumları ile üye devletler ve Avrupa Parlamentosu arasında oluşan -üye devletlerden $A B$ 'ye gücün transfer edilmesi sonucu ortaya çıkan - güç boşluğu, "demokrasi açığı" olarak isimlendirilmektedir (Dinan, 2008: 73). Bu durum, üye 
devletlerin ulusal parlamento seçimleri (birinci sınıf seçimler) ile Avrupa Parlamentosu seçimleri (ikinci sınıf seçimler) arasında bir derece farkının ortaya çıkmasına sebep olmaktadır. Dolayısıyla Avrupa Parlamentosu seçimlerine katılımın düşük olması, birinci sınıf ve ikinci sınıf seçimler arasındaki farkla açıklanabilir. Birinci sınıf (ulusal seçimler) seçimlerde seçmenlerin - seçim sonuçlarına göre - değiştirebilme yetkisine sahip oldukları ulusal yasama ve yürütme organları belirlenmektedir. Bir başka deyişle, ulusal seçimler, seçmenlerin hayatına doğrudan etki göstermekte, dolayısıyla ulusal seçimler vatandaşlar tarafından daha önemli görülmektedir. İkinci sınıf (AP seçimleri) seçimlerde ise seçim sonuçları uyarınca bir hükümet değişikliği olmadığı için vatandaşların hayatına doğrudan bir etkileri yoktur. Ayrıca, seçmenler Avrupa düzeyindeki gündeme ve konulara kendi ulusal düzeylerindeki gündem ve konulardan daha uzak olduklarından Avrupa Parlamentosu seçimlerini daha az önemli görmektedirler.

Altıncı özellik, antlaşmalar ve referandumlar yoluyla $A B$ vatandaşlarının $A B$ siyasetine aktif katılımının sağlanması çabalarıdır. Lizbon Antlaşması'nın getirdiği ve vatandaşların Birlik içindeki aktif katılımını sağlayan en önemli gelişme, "vatandaş girişimi" olarak bilinen atılımdır. Avrupa Birliği Antlaşması'nın 11 (4) maddesi göre "kayda değer sayıdaki üye devletten en az bir milyon Birlik vatandaşı, Antlaşmaların uygulanması amacıyla Birliğin bir hukuk tasarrufunun gerekli olduğunu düşündükleri konularda, Avrupa Komisyonu'nu yetkileri çerçevesinde her türlü uygun öneriyi sunmaya davet etme girişimde bulunabilir" (T.C. Başbakanlık Avrupa Birliği Genel Sekreterliği, 2011: 7). Vatandaş girişimi, hem Birlik vatandaşlarına $A B$ karar alma sürecine aktif olarak katılma fırsatı sunmakta hem de vatandaşlar ile AB kurumları arasında bir köprü oluşturmaktadır (Göçmen, 2011: 508).

Antlaşmaların yanında ulusal referandumlar da Avrupalı seçmenlerin önemli konularda düşüncelerini ifade etmelerine ve $A B$ ölçeğinde karar alma mekanizmasına aktif olarak katılmalarına olanak vermektedir. Avrupa'da referandumlar daha çok üyelik ile ilgili olarak, katılıp katılmama konusunda veya üye devlet hükümetleri tarafından kabul edilen yeni bir antlaşmaya taraf olup olmama konusunda yapılmaktadır. Örneğin, Norveç vatandaşları 1972 yılında (ve sonra yeniden 1994 yılında) yapılan referandumla Topluluk dışında kalırken, İrlanda, Nice Antlaşması'nı 2001 yılında yapılan ilk referandumda onaylamamıştır (Mc Cormick, 2014: 198-200). Ayrıca, "Bölgesel ve Yerel Demokrasi" aracılığı ile yerel yönetimle ilgili $A B$ politikalarının uygulama sorumluluğunun $A B$ vatandaşları tarafından üstenilmesi (Okçu, 2007: 305) vatandaşların aktif katıımını artırmaktadır. Benzer şekilde, 2013 yılında ilan edilen “Avrupa Vatandaşlar Yılı” gibi girişimler, AB vatandaşlarının yerel otoriteler, kamu politika araştırma kurumları ve sivil toplum kuruluşları içinde aktif rol alma çabalarına örnek olarak gösterilebilir.

\section{Sonuç}

Çalışmanın bulguları bize $A B$ vatandaşlarının Avrupa Parlamentosu yoluyla $A B$ siyasetine aktif katılımının ve dolayısıyla Avrupa bütünleşme projesine verdikleri desteğin son derece önemli olduğunu ortaya koymuştur. Günümüze kadar izlediğimiz Avrupa bütünleşme sürecinin en önemli dinamiklerinden biri, $A B^{\prime}$ nin her zaman federal - ulusal dengeyi sağlamış olmasıdır. Avrupa 
siyasetinde bu dengeyi sağlayan en önemli unsur Avrupa Parlamentosu'nda merkezde, ılımlı politikalar izleyen siyasi parti gruplarının gücü ellerinde bulundurmalarıdır. Bunu sağlayan da $A B$ vatandaşlarının merkezde, ılımlı siyasi tercihlere sahip olmasıdır. Hem seçim sonuçlarında hem de Eurobarometer tarafından yapılan anketlerde gördüğümüz gibi çoğunlukla kendisini ideolojik olarak "ortada" tanımlayan AB seçmeni, 1979'da yapılan ilk doğrudan genel seçimlerde ortaya koyduğu bu eğilimini, iniş-çıkışlarına rağmen, 2019 seçimlerinde de devam ettirmiştir. AB seçmeni, 11 Eylül saldırıları ile güvenlik, 2008 krizi ile finansal ve Arap Baharı/Suriye krizi ile mülteci sorunları yaşamasına ve bu olayların etkisiyle radikal/aşırı sağ tercihlere savrulmasına rağmen yine de merkezdeki siyasi parti gruplarını (zaman zaman yerleri değişse de) ilk iki sıraya yerleştirebilmiştir. Bu eğilim AB vatandaşlarının krizler karşısında tutucu yanlarını ortaya koyduklarını ancak neticede ılımlı görüşlerini terk etmediklerini göstermektedir. Dolayısıyla, $A B$ vatandaşlarının bu siyasi eğilimi, Avrupa bütünleşme projesini dengede tutan en önemli özelliklerden biridir.

Avrupa bütünleşme projesinde başarıya ulaşılması, $A B$ vatandaşlarının $A B$ siyasetine aktif katılımına ve bu da $A B$ 'nin - Lizbon Antlaşması'nda bir kez daha vurgulandığı gibi - gerçek bir "temsili demokrasi" olmasına bağııdır. Anayasa Antlaşması ile başarısızlığa uğrayan $A B$ yöneticileri, sorunun çözümünü $A B$ vatandaşlarının $A P$ yoluyla $A B$ siyasetine aktif katılımında bulmuşlardır. Lizbon Antlaşması ile getirilen ve uygulanmaya başlanan yenilikler de bu düşüncenin eseridir. 2014 yılında yapılan seçimlerde alınan sonuçlar, Avrupa'da yabancı düşmanlığı, mülteci sorunu, ekonomik kriz ve terörizm kaynaklı güvenlik sorunlarıyla karşı karşıya kalan $A B$ vatandaşlarının kendi siyasi eğilimlerinden ne kadar sapabileceklerini göstermiş, bu seçimler $A B$ vatandaşları için bir test olmuştur. Brexit süreciyle Avrupa Birliği'nin geleceğini de sorgulayan AB vatandaşları, karşılaştıkları sorunlara sağduyulu tepkiler verebildiklerini 2019 yılında yapılan AP seçimlerinde göstermişlerdir. Seçimlerde korkulan olmamış, radikal siyasi parti grupları $A P^{\prime}$ de gücü ellerine geçirememiş, $A P^{\prime}$ de merkezdeki siyasi parti gruplarının ilk iki sırayı paylaştıkları (ciddi oranlarda sandalye kaybetmelerine rağmen) gelenek bozulmamıştır. Uzun bir süre sonra seçimlere katıımın yeniden \% 50'ye ulaşması ve özellikle gençlerin seçimlere ilgi duyması önemli gelişmeler olarak kaydedilebilir. 2019 seçimleri bize aynı zamanda "Yeşillerin" savundukları toplumsal konuların, AB vatandaşları ve özellikle gençler arasında önem atfedilen konular arasında üst sırlara çıktığını göstermiştir. Bu da dünyada gittikçe daha fazla önem kazanmaya başlayan çevrenin korunması, sürdürülebilir gelişme gibi toplumsal konuların $A B$ vatandaşları için üzerinde düşünülen, önemli konular olmaya başladığını göstermektedir. Sonuç olarak, bu çalışmada ortaya koyulan bulgular bize Avrupa bütünleşme projesinde Avrupa Parlamentosu ile $A B$ vatandaşlarının vazgeçilmez olduğunu, dolayısıyla $A B$ vatandaşlarının Avrupa Parlamentosu yoluyla $A B$ siyasetine daha aktif katılımlarının sağlanmasının bu projeye önemli katkı sağlayacağını göstermektedir.

\section{Araştırma ve Yayın Etiği Beyanı}

Makalenin veri toplama süreci 2020 yılından önce yapılmıştır. Bu nedenle etik kurul iznine gerek bulunmamaktadır. 


\section{Yazarların Makaleye Katkı Oranları}

Bu makale yazar tarafından tek başına hazırlanmıştır.

\section{Çıkar Beyanı}

Bu makale ile ilgili herhangi bir çıkar çatışması bulunmamaktadır.

\section{Kaynaklar}

About Parliament. (2019). 03.06.2019 tarihinde http://www.europarl.europa.eu/aboutparliament/en/in-the-past/previous-elections adresinden alındı.

ECR Group, About. (2019). 04.06.2019 tarihinde https://ecrgroup.eu/about adresinden alındı.

ECR Group, Protecting and Respecting Member States. (2019). 04.06.2019 tarihinde https://ecrgroup.eu/vision/protecting and respecting member states adresinden alındı.

EPP Group in the European Parliament. (2019). 03.06.2019 tarihinde https://www.eppgroup.eu/ adresinden alındı.

EPP Group, Our Missions and Values. (2019). 03.06.2019 tarihinde https://www.eppgroup.eu/what-we-stand-for/missions-values adresinden alındı.

Eurobarometer Survey 91,5. (2019). Have European elections entered a new dimension?

European Election Results. (2019). 03.06.2019 tarihinde https://www.electionresults.eu/european-results/2019-2024/ adresinden alındı.

European Election Results, Germany. (2019). 03.06.2019 tarihinde https://europarl.europa.eu/election-results-2019/en/nationalresults/germany/2019-2024/adresinden alındı.

European Election Results, France. (2019). 03.06.2019 tarihinde https://europarl.europa.eu/election-results-2019/en/national-results/france/20192024/ adresinden alındı.

European Election Results, Italy. (2019). 03.06.2019 tarihinde https://europarl.europa.eu/election-results-2019/en/national-results/italy/20192024/ adresinden alındı.

European Election Results, Spain. (2019). 03.06.2019 tarihinde https://europarl.europa.eu/election-results-2019/en/national-results/spain/20192024/ adresinden alındı

European Election Results, United-Kingdom. (2019). 03.06.2019 tarihinde https://europarl.europa.eu/election-results-2019/en/national-results/unitedkingdom/2019-2024/adresinden alındı.

Dınan, D. (2008). Avrupa Birliği tarihi (Çev. Hale Akay), İstanbul: Kitap Yayınevi. Göçmen, I. (2011). Avrupa Birliği'nde vatandaş girişimi”, Prof. Dr. Ahmet Gökdere'ye armağan, Ankara: Turhan Kitabevi. 
Gue/NGL, History. (2019). 04.06.2019 tarihinde https://www.guengl.eu/history/ adresinden alındı.

GUE/NGL, About The Group. (2019). 04.06.2019 tarihinde https://www.guengl.eu/aboutthe-group/adresinden alındı.

GUE/NGL, New Report: Towards A Progressive Trade Politics in The EU. (2019). 04.06.2019 tarihinde https://www.guengl.eu/new-report-released-towards-a-progressive-tradepolitics-in-the-eu/ adresinden alındı.

Günuğur, H. (2014). Avrupa Birliği, genişletilmiş ve güncellenmiş, (3. bs). Ankara: Avrupa Ekonomik Danışma Merkezi Yayını.

Heywood, A. (2016). Siyasetin ve uluslararası ilişkilerin temel kavramları (Çev. Fahri Bakırcı), (3. bs). Ankara: BB101.

Identity and Democracy Party. (2019). 04.06.2019 tarihinde https://www.id-party.eu adresinden alındı.

Kaymakçı, F. (2019). European Parliament elections: a new political environment in Europe and Turkey. Insight Turkey, 21(3), 23-30.

Kiriş, M. H. (2013). Avrupa Parlamentosu'nda siyasal gruplar ve Parlamento seçimleri. Selçuk Üniversitesi Sosyal Bilimler Enstitüsü Dergisi, 29, 123-135.

News, European Parliament. (2019). 04.06.2019 tarihinde www.europarl.europa.eu/news/en/press-room/20190710IPR56721/2019-euelections-a-pro-european-and-young-electorate-with-clear-expectations adresinden alındı.

Mc Cormıck, J. (2014). Avrupa Birliği'ni anlamak (Çev. Yusuf Şahin, Hasan Hüseyin Şahin), Ankara: Big Bang.

Noi, Ü. A. (2012). Arap baharı ve Türkiye-Avrupa Birliği ilişkileri, Ortadoğu Analiz, 4(48), 1019

Okçu, M. (2007). Yönetişim tartışmalarına katkı: Avrupa Birliği için yönetişim ne anlama geliyor? Süleyman Demirel Üniversitesi, i.i.B.F. 12 (3), 299-312

Renew Europe. (2019). 04.06.2019 tarihinde https://alde.eu/en/about-us/ adresinden alındı.

Rudden, B. ve D. Wyatt (1986). Basic community law, Oxford: Clarendon Press.

Special Eurobarometer 486. (2019). Report, European 2019.

Special Eurobarometer 477. (2018). Summary, Democracy and Election.

Standard Eurobarometer 90. (2018). Report, public opinion in the European Union.

T.C. Başbakanlık Avrupa Birliği Genel Sekreterliği. (2011). Avrupa Birliği Antlaşması ve Avrupa Birliği'nin Işsleyişi hakkında Antlaşma, Ankara: Ofset Fotomat

The Greens/EFA, About the Group. (2019). 04.06.2019 tarihinde https://www.greensefa.eu/en/our-group/about-greens-efa/ adresinden alındı. 